\title{
My Journey to Reform the Rockefeller Drug Laws Anthony Papa
}

$\mathrm{O}$ April 24, 2009, I attended an historic bill-signing ceremony that hammered another nail into the coffin of the Rockefeller Drug Laws. In Corona, Queens, at the Elmcor Community Center. Governor Paterson signed the document to put into place the reforms that activists like me had sought for thirty-six years. Standing tall at a podium, Patterson said, "For years, thousands of New Yorkers have spoken out against the Rockefeller Drug Laws... This is a proud day for me and so many of my colleagues who have fought for so long to overhaul the drug laws and restore judicial discretion in narcotics cases".

The Rockefeller Drug Laws were enacted in 1973 by the New York State Legislature to satisfy Governor Nelson Rockefeller's attempt to curb the drug epidemic of that time. Harsh mandatory minimum sentences were imposed on those caught selling two ounces or possessing 4 ounces of a controlled substance. Instead of satisfying the legislative intent of locking up major kingpins and curbing the epidemic, it did the opposite, putting first time non-violent offenders away for sentences of 15 years to life. Locking up Blacks and Latinos at alarming rates had a drastic effect on communities of color, and caused the New York's State's prison system to burst at its seams.

The new bill not only restored judicial discretion in most drug cases, but also expanded alternatives to incarceration and invested millions in treatment. Activists like Gabriel Sayegh, project director with the Drug Policy Alliance said, "Governor Paterson has helped to move our state in a new direction on drug policy, one based on public health and safety, in fairness and justice. This shows what is possible when people come together and work for change". While advocates applaud the changes, they also point out that reforms should have gone even further. For instance, some mandatory minimum sentences for drug offenses still remain intact, and harsh penalties for low-level drug offenses remain on the books.

This day was a total vindication for me, because in 1985 I was given a 15-years-to-life sentence for a first time non-violent drug offense. Nothing in the world could have prepared me for life in the gulag. I was sent to Sing Sing, a maximum security prison in Ossining, New York. It was a living nightmare. Not only did I lose my family, I lost my life as I knew it. When I arrived at the prison, I was surrounded by a sea of faces of men who had lost all faith in their lives. It was the lowest point in my life. 
Soon after, I was walking past a row of cells on the top tier of the A Block housing unit. I smelled paint and followed its trail to a cell. I looked in and saw the most magnificent paintings They belonged to a prisoner named Indio. We became friends and he taught me how to paint.

I became absorbed in my art. I was hooked. In 1988, I was sitting in my cell and picked up a mirror. I saw a man who was going to be spending the most productive years of his life locked in a cage. I set up a canvas and captured the image, which I named "15 to Life". In 1994 this self-portrait was exhibited at the Whitney Museum of American Art where it received a lot of media attention. In 1997, after 12 years in prison, I received executive clemency from Governor George Pataki. Upon release I began having exhibits and used my art as an instrument to speak out against inhumane drug laws.

At the same time I traveled to Albany to speak with legislators, most of whom had a dual view of reforming the laws. Their public view was that the Rockefeller Drug Laws were working fine, but behind closed doors they agreed that they needed to be reformed. They were afraid of speaking out against them, because it would cause their political deaths.

To try to change the way politicians thought about New York's drug laws, we had to change their constituents' views. In 1998, I co-founded the Mothers of the New York Disappeared. The group was modeled on their Argentinean counterparts. The Madres of the Plaza de Mayo have marched weekly since the 1970s in front of the Casa Rosada (the Presidential palace), bearing photos of their children and grandchildren "disappeared" during the military dictatorship.

In 1997, we passed out flyers at a bus terminal to family members that took buses up to New York State prisons and requested those who had loved ones imprisoned by the Rockefeller Drug Laws to join our group. The request was looked upon by some as a blessing because they wanted to help change the laws that imprisoned many of their relatives. On May 8, 1998, about 25 family members of people imprisoned by the Drug Laws demonstrated at Rockefeller Center at $50^{\text {th }}$ Street and Fifth Avenue in NYC. Putting faces on those who were "doing time outside" generated a lot of press.

Several years later the media had a field day when a delegation of Madres - one of them now seventy-eight - flew from Buenos Aires, wearing their emblematic white scarves, to join the New York Mothers at a press conference on the steps of City Hall to protest the Rockefeller Drug Laws. 
We made a trip to Albany New York where they met with members of the New York Assembly and Senate. Robert Morganthau, the New York City District Attorney, was so impressed with them he gave them a private tour of his NYC office and did a photo shoot with the Madres.

It was a long row to hoe, but we eventually shifted public opinion, which then put pressure on the politicians. In 2004-2005, we got the first changes in the law, but they were watered-down, and activists like myself were not satisfied and pushed for further reform. Even these changes did not come easily because of the New York State legislature's reluctance to tamper with the quagmire created by Governor Nelson Rockefeller in 1973.

Some had considered the Rockefeller Laws the answer to the so-called drug epidemic. But the harsh sentencing guidelines with their mandatory minimums did nothing more than fuel the prison-industrial complex and give relief to economically depressed rural upstate communities by incarcerating low level non-violent drug offenders. The Rockefeller Laws also led to the building of thirty-eight prisons since 1982, mostly in Republican senate districts, at an operating cost of over a billion dollars annually. Seen as a cash cow for these upstate rural districts, the Rockefeller Laws became an untouchable political issue

Joining upstate politicians were prosecutors who became staunch opponents of any Rockefeller reform legislation. They used the Laws as a powerful prosecutorial tool, claiming to shield society from harm associated with drugs and addiction. But in reality the only effect of the Laws was massive incarceration for hundreds of thousands of low level non-violent drug offenders, who should have had treatment instead. Of these, over 90 percent were Black and Latino. The Rockefeller Drug Laws generated a racist entity that completely failed to balance justice and protection of our communities.

With perseverance and determination we fought for meaningful reform for thirty-six years, and this year we achieved it. Following the new reforms President Obama's new drug czar, former Seattle Police Chief Gil Kerlikowske called for an end to the war on drugs and said we are not at war with people in this country.

I agree. Now it's time to embrace the New Rockefeller Reforms and set free those who received harsh mandatory sentencing and who are eligible for judicial relief, so they may be reunited with their families and start productive lives as citizens of New York. 


\section{ABOUT THE AUTHOR}

Anthony Papa is an artist, writer, noted advocate against the war on drugs and co-founder of the Mothers of the New York Disappeared. His opinion pieces about the drug war have appeared in the Huffington Post, among others. He is a public speaker and college lecturer on art and on criminal justice issues. Currently, he is a communications specialist for Drug Policy Alliance in NYC. Papa is the author of 15 to Life: How I Painted My Way to Freedom (Feral House, 2004), a memoir about his experience of being sentenced to state prison for a first-time, non-violent drug offense under New York's draconian Rockefeller Drug Laws. The New York Times, The Washington Post, The Nation, National Public Radio, "Democracy Now", Court TV, "Extra", and C-Span have interviewed him. Papa has appeared on nationally syndicated talk shows such as "Charles Grodin", "Geraldo Rivera", and "Catherine Crier Live". His art has been exhibited at the Whitney Museum of American Art in New York as well as other venues. 